\title{
Pathologic Features, Proliferative Activity, and Cyclin D1 Expression in Hurthle Cell Neoplasms of the Thyroid
}

Lori A. Erickson, M.D., Long Jin, M.D., John R. Goellner, M.D., Christine Lohse, B.S., V. Shane Pankratz, Ph.D., Lawrence R. Zukerberg, M.D., Geoffrey B. Thompson, M.D., Jon A. van Heerden, M.D., Clive S. Grant, M.D., Ricardo V. Lloyd, M.D., Ph.D.

Departments of Laboratory Medicine and Pathology (LAE, LJ, JRG, RVL), Statistics (CL, VSP), and Surgery (GBT, JAvH, CSG), Mayo Clinic and Mayo Foundation, Rochester, Minnesota, and the Department of Pathology (LRZ), Massachusetts General Hospital, Boston, Massachusetts

Making a histologic distinction between Hurthle cell adenomas and carcinomas sometimes may be difficult. We analyzed a series of Hurthle cell lesions to determine whether specific histologic features and expression of Ki67 and cyclin D1 could be useful in distinguishing Hurthle cell adenomas from carcinomas. Formalin-fixed, paraffin-embedded tissues from 128 Hurthle cell neoplasms, including 59 adenomas; 55 carcinomas; and 14 tumors classified as neoplasms of uncertain malignant behavior (UMB), which had equivocal capsular invasion but no vascular invasion, were analyzed for expression of Ki67 and cyclin D1 by immunostaining. The distribution of immunoreactivity for Ki67 with antibody MIB-1 was analyzed by quantifying the percentage of positive nuclei that was expressed as the labeling index.

None of the patients with adenomas or UMB tumors developed recurrent or metastatic disease after a mean follow-up of 7.8 and 7.9 years, respectively. Of the 55 patients with Hurthle cell carcinoma, 19 were associated with metastatic disease, 13 of whom died with disease. No patient with a Hurthle cell carcinoma without vascular invasion developed metastatic disease. The mean tumor size for Hurthle cell carcinomas $(4.8 \mathrm{~cm})$ was significantly larger than that of Hurthle cell adenomas $(3.1 \mathrm{~cm})$ or UMB tumors $(3.7$ cm). No patient with a Hurthle cell tumor smaller than $3.5 \mathrm{~cm}$ developed metastatic disease, even when vascular invasion was present. The Ki67 labeling index in Hurthle cell carcinomas $(10.0 \pm 1.2)$ was 3-fold higher than in Hurthle cell adenomas $(3.2 \pm 0.3)$. The Ki67 labeling index in the UMB group was $5.0 \pm 0.7$. Cyclin D1 showed diffuse nuclear staining in 1 of the $59(1.7 \%)$ Hurthle cell

Copyright (C) 2000 by The United States and Canadian Academy of Pathology, Inc.

VOL. 13, NO. 2, P. 186, 2000 Printed in the U.S.A

Date of acceptance: August 25, 1999.

Address reprint requests to: Dr. R.V. Lloyd, Laboratory Medicine and

Pathology, 200 1st Street SW, Rochester, MN 55905; fax: 507-284-1599. adenomas, in 10 of the 55 (18\%) Hurthle cell carcinomas, and in none of the UMB tumors.

In summary, analyses of the cell cycle proteins Ki67 and cyclin D1 in Hurthle cell thyroid neoplasms indicate that these markers may assist in distinguishing some Hurthle cell carcinomas from adenomas. Among the Hurthle cell carcinomas, large tumor size and vascular invasion are associated with clinically aggressive tumors. Our study also suggests that Hurthle cell neoplasms with only equivocal capsular invasion and no vascular invasion should behave in a benign manner.

KEY WORDS: Cyclin D1, Hurthle cell, Ki67, Thyroid. Mod Pathol 2000;13(2):186-192

Hurthle cell neoplasms are uncommon thyroid tumors with Hurthle cell carcinoma composing only 2 to $3 \%$ of all cases of thyroid carcinoma (1). The majority of these tumors can be readily diagnosed by characteristic histopathologic features. However, making a distinction between Hurthle cell adenoma and Hurthle cell carcinoma sometimes can be difficult. Thus, additional diagnostic features that can assist in this determination would be clinically useful.

Recent studies suggested that Ki67, a proliferation marker, and cyclin D1, a cell cycle regulatory protein, may be important in predicting behavior of various thyroid tumors (2-6). The proliferation marker Ki67 is expressed in all stages of the cell cycle, except G0 (7). Carr et al. (2) showed that high rates of proliferation, as measured by the MIB-1 antibody to Ki67, may be helpful in recognizing some thyroid tumors with more aggressive behavior. Another study demonstrated that follicular carcinomas expressed significantly higher levels of Ki67 than follicular adenomas, indicating a higher proliferative rate in the malignant tumors (4).

The cell cycle is regulated by a host of cell cyclins, cyclin-dependent kinases, and cyclin-dependent 
kinase inhibitors. Cyclin D1 is a regulator of cell cycle progression from G1 to S phase (8-11). Encoded by a gene on chromosome $11 \mathrm{q} 13(12,13)$, cyclin D1 is overexpressed in many tumors (14-26). It is interesting that overexpression of cyclin D1 is seen in a variety of tumors without amplification or genetic alteration of the cyclin D1 gene $(14,21)$. Recent studies suggested that cyclin D1 may have a role in thyroid tumorigenesis $(5,6)$. Zou et al. (5) found a 4- to 5 -fold increase in cyclin D1 expression in a subset of thyroid papillary carcinomas, as compared with benign nodular goiters. No evidence of cyclin D1 gene amplification or rearrangement was found to account for the increase in cyclin D1 expression (5). Lazzereschi et al. (6) also found cyclin D1 to be overexpressed in a subset of papillary carcinomas without genetic alteration or amplification. The goals of this study were to analyze the histologic features and the expression of Ki67 and cyclin D1 in Hurthle cell neoplasms of the thyroid and the usefulness of histopathologic features and immunohistochemical markers in distinguishing Hurthle cell adenomas from carcinomas.

\section{MATERIALS AND METHODS}

\section{Cases and Tissues}

Formalin-fixed, paraffin-embedded tissue blocks from 128 randomly selected patients who underwent surgery at the Mayo Clinic, Rochester, MN, between 1962 and 1995 were used. These included 59 Hurthle cell adenomas, 55 Hurthle cell carcinomas, and 14 Hurthle cell neoplasms of uncertain malignant behavior (UMB). Hematoxylin- and eosin-stained sections were reviewed independently by three of the authors (LAE, JRG, RVL) for verification of diagnoses (Fig. 1). By definition, the neoplasms were composed exclusively or predominantly (more than 75\%) of follicular cells exhibiting Hurthle cell features (27). Focal architectural papillary features were identified in five cases; however, these tumors did not have the nuclear features of papillary thyroid carcinoma. Neoplasms that were composed of fewer than $75 \%$ of follicular cells exhibiting Hurthle cell features (two cases) were excluded. All tumors with oncocytic cytoplasmic features and nuclear features of papillary carcinomas as recently described (28) were also excluded.

The mean number of sections of the tumorcapsular interface evaluated in the Hurthle cell carcinoma cases was 7.2 (range, 1 to 23). Two cases of Hurthle cell carcinoma with only capsular invasion each had only one section evaluated. Both were small tumors, $1.1 \mathrm{~cm}$ and $2 \mathrm{~cm}$, and additional deeper sections were cut from the blocks to evaluate for vascular invasion. The mean number of sections evaluated for Hurthle cell carcinomas with

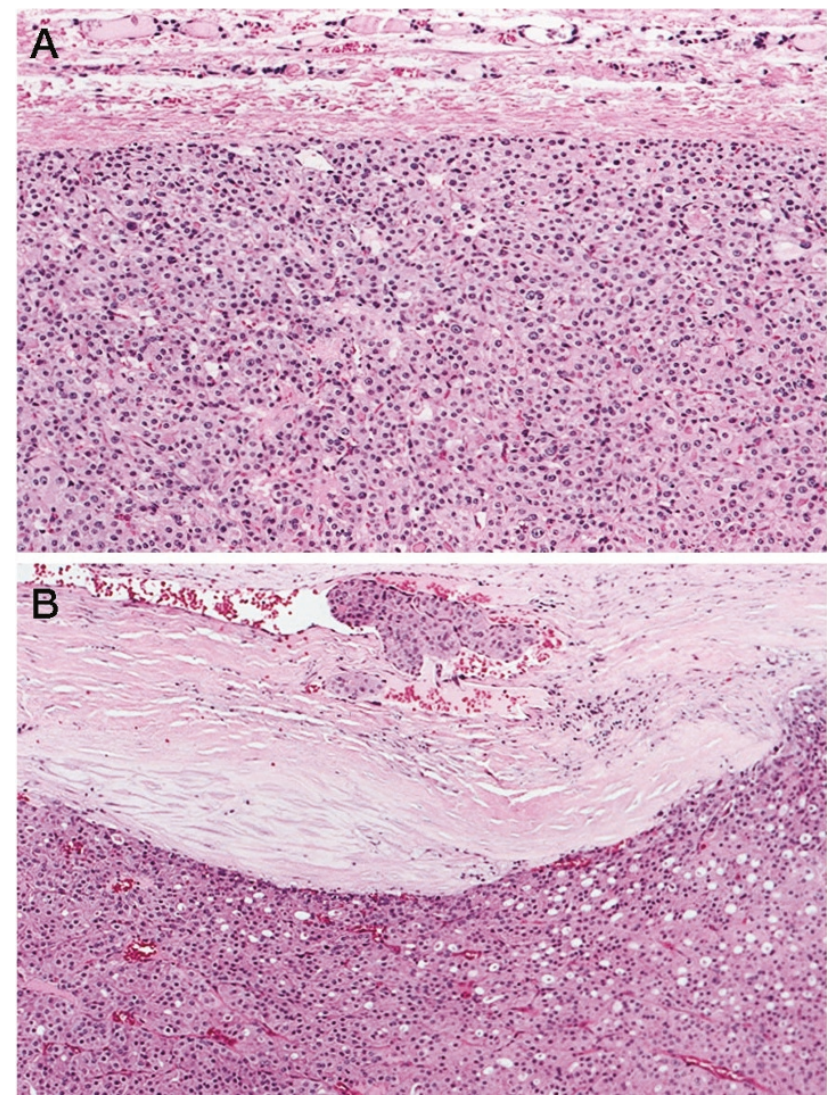

FIGURE 1. Histologic examples of Hurthle cell neoplasms analyzed. A, Hurthle cell adenoma composed exclusively of follicular cells exhibiting oncocytic features in a follicular growth pattern. B, Hurthle cell carcinoma with vascular invasion.

vascular invasion was 7.0. The mean number of sections evaluated for Hurthle cell carcinomas with only capsular invasion was 8.8 . When available, the original wet tissue was reexamined and additional sections were taken to evaluate for vascular invasion.

Neoplasms classified as adenomas were single lesions, encapsulated, and microscopically uniform and usually compressed the non-neoplastic gland. Hurthle cell adenomas did not show capsular or vascular invasion. Neoplasms classified as carcinomas showed unequivocal capsular and/or vascular invasion. Tumors with unequivocal capsular invasion had tumor cells penetrating through the entire thickness of the capsule. Vascular invasion was defined as tumor cells partly or completely obliterating a vessel located within or outside the capsule with tumor cells attached to the vessel wall. Lesions with no vascular invasion and only questionable capsular invasion (i.e., nests of tumor cells present in the capsule but not penetrating completely through the capsule) were classified as Hurthle cell UMB neoplasms, analogous to the designation that Rosai et al. (27) used for follicular neoplasms with similar characteristics. All of the UMB tumors were originally diagnosed as Hurthle cell carcinomas, 
but in reevaluation of all of the material available for this study, no unequivocal invasion, either vascular or capsular, was identified.

\section{Patient Information}

Patient history and follow-up information were obtained by chart review. Clinical information, including age, gender, mean follow-up, tumor size, and metastatic disease, are summarized in Table 1.

\section{Immunohistochemical Analysis}

Formalin-fixed, paraffin-embedded tissue sections were cut at $5 \mu \mathrm{m}$ and treated with $0.1 \mathrm{~mol} / \mathrm{L}$ citrate, $\mathrm{pH} 6.0$, in an 800-W microwave oven for 15 min for antigen retrieval before immunostaining. A monoclonal antibody to Ki67 (AMAC, Westbrook, ME) was used at a 1:50 dilution. The rabbit polyclonal anti-cyclin D1 antibody was used at a 1:500 dilution as previously reported (22). Antigen retrieval by microwaving was done for $15 \mathrm{~min}$ as previously reported (4). Immunostaining was done with the Elite avidin-biotin-peroxidase kit (Vector Laboratories, Burlingame, CA), according to the manufacturer's specifications. Slides were counterstained with hematoxylin for 1 second. Tonsil tissues, positive for both Ki67 and cyclin D1, were used as positive controls. Normal mouse or rabbit sera were substituted for the primary antibodies as negative controls.

\section{Quantitation}

The distribution of immunoreactivity was analyzed by quantifying nuclear staining in each case without knowledge of the diagnosis or outcome. The percentages of cells expressing Ki67 were determined by counting 1000 cells per slide with the aid of an ocular $10 \times 10-\mathrm{mm}$ grid (LJ). Ki67immunoreactive cells were counted in areas of highest density of staining over a minimum of 10 high power fields, because of the low percentage of cells staining positive for Ki67 in benign thyroid tissue. This method of estimating Ki67 labeling has been used by other investigators in studies of thyroid and parathyroid tumors and to evaluate mitotic activity in adrenal cortical neoplasms (4, 29, 30 ). The percentage of positive nuclei was expressed as the labeling index (LI). When $10 \%$ of the cases were blindly recounted for Ki67, the LIs did not vary more than $\pm 10 \%$ from the original count. LIs were expressed as the mean \pm standard error of the mean for the Ki67 labeling. The percentages of cyclin D1 positive nuclei were estimated as no nuclear staining, less than $5 \%$ positive nuclei, 5 to $25 \%$ positive nuclei, and more than $25 \%$ positive nuclei for the entire section.

\section{Statistics}

Differences among the three tumor groups for our parameters of interest were assessed using Kruskal-Wallis and Fisher's exact tests. Pairwise differences were evaluated using paired $t$ tests, Wilcoxon rank sum test, and Fisher's exact test. We assessed the association between metastases and our parameters of interest using log linear models for discrete parameters and logistic regression for the continuous ones.

\section{RESULTS}

The clinicopathologic features of the cases studied are summarized in Table 1. The mean follow-up period ranged from 7.8 to 10.1 years for the groups. No patient with a Hurthle cell adenoma or a UMB tumor developed metastatic disease. Metastatic disease was identified in 19 of the 55 patients with Hurthle cell carcinomas, with 11 patients showing metastatic disease at the time of thyroid surgery. Females composed approximately $68 \%$ of the patients in the adenoma group, $56 \%$ in the carcinoma group, and $50 \%$ in the UMB group. Among the Hurthle cell carcinomas, a significantly higher percentage of males (13 of 24; 54\%) than females (6 of $31 ; 19 \%)$ developed metastatic disease $(P=.007)$. Follow-up of the 55 patients with Hurthle cell carcinomas showed 27 alive without disease, 3 alive with disease, 12 dead without disease, and 13 dead of disease.

All of the Hurthle cell lesions were composed of more than $75 \%$ follicular cells with oncocytic or oxyphil features (Fig. 1). Hurthle cell adenomas were single, encapsulated, uniform tumors without capsular or vascular invasion. Hurthle cell carcinomas showed unequivocal capsular and/or vascular invasion. Forty-six of the 55 Hurthle cell carcinomas showed vascular invasion, and the other 9

TABLE 1. Clinical and Pathologic Features of Hurthle Cell Neoplasms

\begin{tabular}{|c|c|c|c|c|c|c|c|}
\hline Diagnosis & $N$ & $\begin{array}{l}\text { Mean age } \\
(\mathrm{yr})\end{array}$ & $\begin{array}{l}\text { Female/ } \\
\text { Male }\end{array}$ & $\begin{array}{c}\text { Mean Follow-Up } \\
(\mathrm{yr})\end{array}$ & $\begin{array}{l}\text { Mean Tumor } \\
\text { Size }(\mathrm{cm})\end{array}$ & $\begin{array}{c}\text { Metastatic } \\
\text { Disease }\end{array}$ & $\begin{array}{l}\text { Dead of } \\
\text { Disease }\end{array}$ \\
\hline Hurthle cell adenoma & 59 & 60 & $40 / 19$ & 7.8 & 3.1 & 0 & 0 \\
\hline UMB & 14 & 52 & $7 / 7$ & 7.9 & 3.7 & 0 & 0 \\
\hline Hurthle cell carcinoma & 55 & 60 & $31 / 24$ & 10.1 & $4.8^{a}$ & 19 & 13 \\
\hline
\end{tabular}

UMB, uncertain malignant behavior.

${ }^{a}$ Hurthle cell carcinomas were significantly larger than Hurthle cell adenomas $(p=.0003)$. 
cases showed only capsular invasion. Hurthle cell neoplasms of uncertain malignant behavior showed no vascular invasion and only indefinite capsular invasion. In predicting the development of metastatic disease on the basis of histopathologic features, the type of invasion (vascular versus capsular) was significant $(P=.017)$. Nineteen of the 46 Hurthle cell carcinomas with vascular invasion were associated with metastatic disease, whereas none of the patients with Hurthle cell carcinoma with only capsular invasion (no vascular invasion) developed metastatic disease.

The mean tumor size of Hurthle cell carcinomas $(4.8 \mathrm{~cm}$; range, 1.1 to $12 \mathrm{~cm}$ ) was significantly larger than that of Hurthle cell adenomas $(3.1 \mathrm{~cm}$; range, 0.5 to $8 \mathrm{~cm} ; P=.0003$; Table 1). Hurthle cell carcinomas with vascular invasion $(5.3 \mathrm{~cm}$; range, 1.5 to $12 \mathrm{~cm}$ ) were significantly larger than those with only capsular invasion $(2.5 \mathrm{~cm}$; range, 1.1 to $4 \mathrm{~cm}$; $P=.0017$; Table 2). The mean tumor size of Hurthle cell carcinomas with metastatic disease $(7.1 \mathrm{~cm}$; range, 3.5 to $12 \mathrm{~cm}$ ) was significantly greater than that of those without metastatic disease $(3.5 \mathrm{~cm}$; range, 1.1 to $8 \mathrm{~cm} ; P=.0000$; Table 3). No patient with a Hurthle cell carcinoma smaller than $3.5 \mathrm{~cm}$ developed metastatic disease, even in the presence of vascular invasion.

Immunohistochemical staining revealed nuclear localization of both Ki67 and cyclin D1 proteins in all groups of Hurthle cell tumors (Fig. 2). Analysis of the three groups of Hurthle cell neoplasms showed a lower percentage of adenomas and UMB cells immunostaining for Ki67 than carcinoma cells (Fig. 3 and Table 4). Hurthle cell adenomas had a slightly lower Ki67 LI than UMB tumors. Hurthle cell carcinomas $(10.0 \pm 1.2)$ had a significantly higher Ki67 LI than Hurthle cell adenomas $(3.2 \pm 0.3 ; P<.0001)$ and UMB tumors (5.0 $\pm 0.7 ; P=.0439$; Table 4). Hurthle cell carcinomas with vascular invasion had a significantly higher Ki67 LI (11.0) than the carcinomas without vascular invasion (LI, $4.5 ; P=.0174$; Table 5). Similarly, Hurthle cell carcinomas with metastatic disease had a significantly higher Ki67 LI (14.1) than carcinomas without metastatic disease (LI, 7.8; $P=.0033$; Table 2).

TABLE 2. Size, Ki67, and Metastatic Disease in Hurthle Cell Carcinomas with and without Vascular Invasion

\begin{tabular}{ccccc}
\hline $\begin{array}{l}\text { Vascular } \\
\text { Invasion }\end{array}$ & $N$ & $\begin{array}{c}\text { Tumor Size }(\mathrm{cm}) \\
(\text { mean } \pm \text { SEM) }\end{array}$ & $\begin{array}{c}\text { Ki67 Labeling Index } \\
\text { (mean } \pm \text { SEM) }\end{array}$ & $\begin{array}{c}\text { Metastatic } \\
\text { Disease }\end{array}$ \\
\hline Absent & 9 & $2.5 \pm 0.3$ & $4.5 \pm 1.0$ & 0 \\
Present & 46 & $5.3 \pm 0.4^{a}$ & $11.0^{b} \pm 1.4$ & $19^{c}$ \\
\hline
\end{tabular}

SEM, standard error of the mean.

${ }^{a}$ Hurthle cell carcinomas with vascular invasion were significantly larger than those without vascular invasion ( $p=.0017)$.

${ }^{b}$ Hurthle cell carcinomas with vascular invasion had a significantly higher K167 labeling index than those without vascular invasion ( $p=$ .0174).

${ }^{c}$ Metastatic disease was seen in 19 Hurthle cell carcinomas with vascular invasion but in no tumors with only capsular invasion $(p=.011)$.
TABLE 3. Size and Ki67 in Hurthle Cell Carcinomas with and without Metastases

\begin{tabular}{cccc}
\hline $\begin{array}{c}\text { Metastatic } \\
\text { Disease }\end{array}$ & $N$ & $\begin{array}{c}\text { Tumor Size }(\mathrm{cm}) \\
\text { (mean } \pm \text { SEM) }\end{array}$ & $\begin{array}{c}\text { Ki67 Labeling Index } \\
\text { (mean } \pm \text { SEM) }\end{array}$ \\
\hline Absent & 36 & $3.5 \pm 0.3$ & $7.8 \pm 1.3$ \\
Present & 19 & $7.1 \pm 0.5^{a}$ & $14.1 \pm 2.2^{b}$ \\
\hline
\end{tabular}

SEM, standard error of the mean.

${ }^{a}$ Hurthle cell carcinomas with metastatic disease were significantly larger than those without metastatic disease $(p<.0001)$.

${ }^{b}$ Hurthle cell carcinomas with metastatic disease had a significantly higher Ki67 labeling index than those without metastatic disease ( $p=$ .0033).

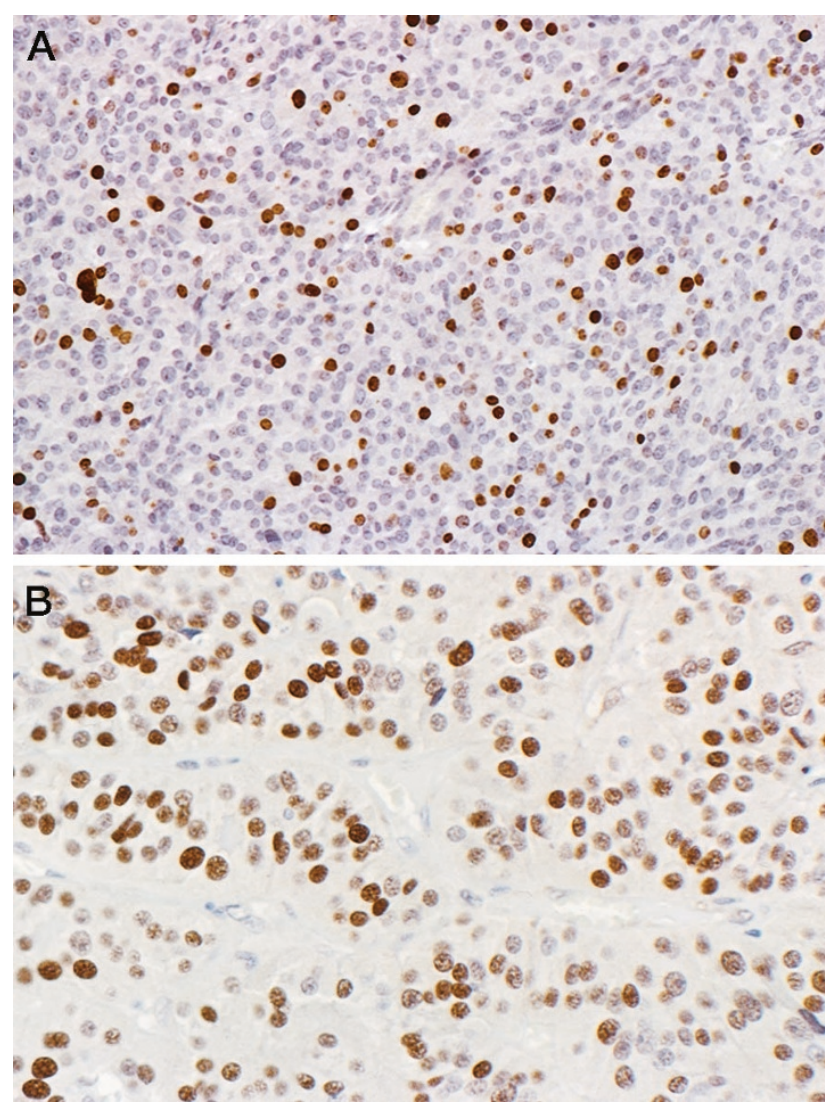

FIGURE 2. Ki67 and cyclin D1 expression in Hurthle cell neoplasms. A, Hurthle cell carcinoma with many nuclei staining strongly for Ki67 and a labeling index of $37 \%$. B, diffuse staining for cyclin D1 in a Hurthle cell carcinoma (more than 25\%).

The results of immunostaining with the antibody to cyclin D1 are summarized in Table 5. Diffuse nuclear cyclin D1 expression (more than $25 \%$ of nuclei positive) occurred more frequently in Hurthle cell carcinomas (18.2\%) compared with adenomas $(1.7 \%)$ or UMB tumors $(0.0 \% ; P=.006$; Table 5). Diffuse nuclear staining was seen in 10 of the $55(18.2 \%)$ Hurthle cell carcinomas, 1 of the 59 (1.7\%) Hurthle cell adenomas, and none of the UMB tumors. Eight of the 10 Hurthle cell carcinomas with diffuse cyclin D1 immunostaining showed vascular invasion. Diffuse staining for cyclin D1 was seen in a greater percentage of Hurthle cell carcinomas with metastatic disease (5 of $19 ; 26 \%$ ) than 


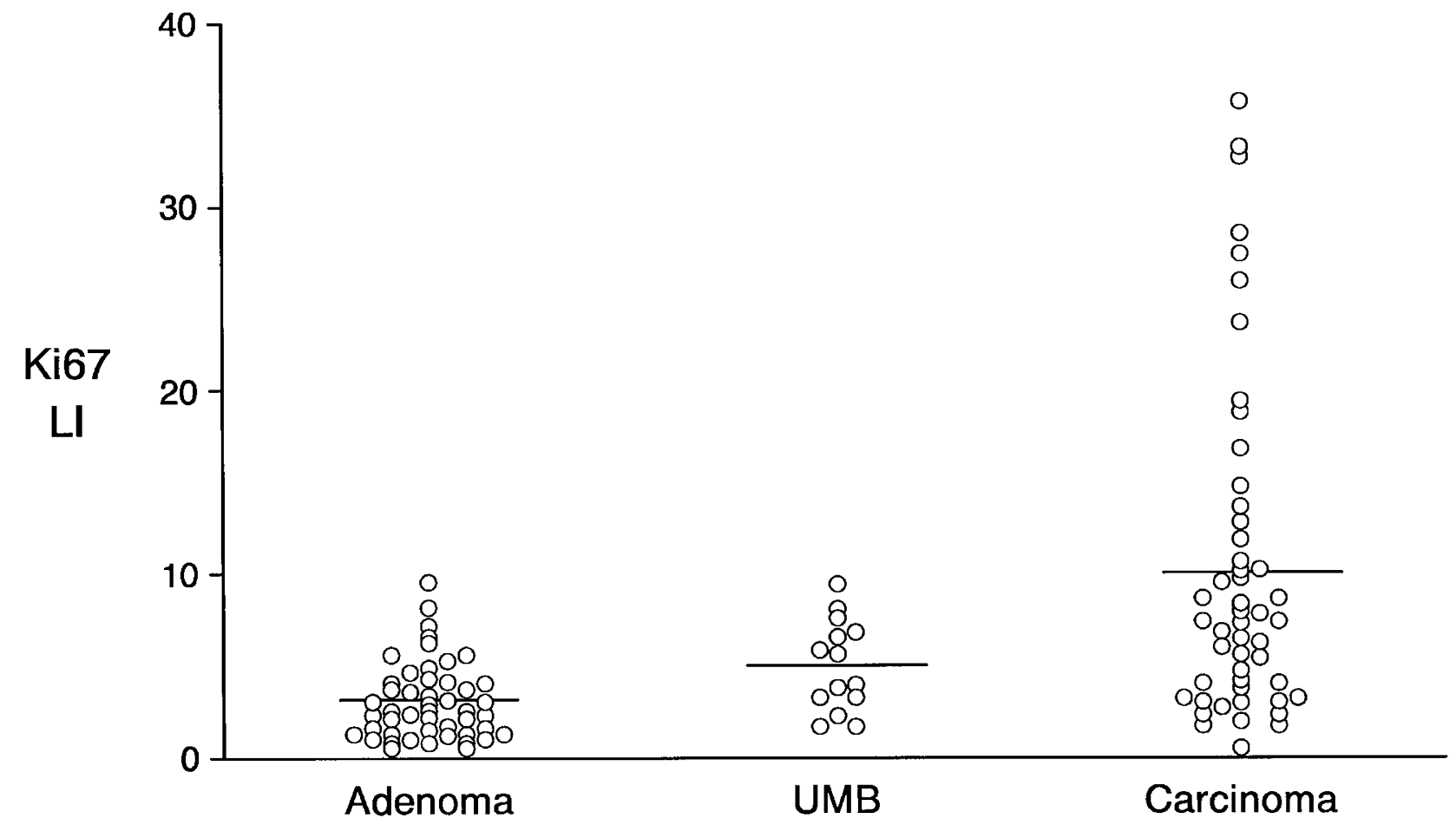

FIGURE 3. Analysis of Ki67 in Hurthle cell neoplasms. The distribution of Ki67 labeling indices and the mean labeling index for each group of neoplasms is shown. Hurthle cell carcinomas had the highest Ki67 labeling index, 3-fold higher than that of Hurthle cell adenomas.

TABLE 4. Ki67 Immunoreactivities in Hurthle Cell Tumors

\begin{tabular}{lcc}
\hline \multicolumn{1}{c}{ Diagnosis } & $N$ & $\begin{array}{c}\text { Ki67 Labeling Index } \\
\text { (mean } \pm \text { SEM) }\end{array}$ \\
\hline Hurthle cell adenoma & 59 & $3.2 \pm 0.3^{a}$ \\
UMB & 14 & $5.0 \pm 0.7$ \\
Hurthle cell carcinoma & 55 & $10.0 \pm 1.2^{b}$ \\
\hline UMB, uncertain malignant behavior. \\
SEM, standard error of the mean. \\
${ }^{a}$ Ki67 for Hurthle cell adenomas compared with UMB group was \\
significantly different ( $p=.0105$ ). \\
${ }^{b}$ Ki67 for Hurthle cell carcinomas compared with adenomas and the \\
UMB group were significantly different ( $p<.0001$ and $p=.0439$, respec- \\
tively).
\end{tabular}

Hurthle cell carcinomas without metastatic disease (5 of 36; 14\%), although these results did not reach statistical significance.

\section{DISCUSSION}

Analysis of the cell cycle proliferation marker Ki67 showed significant differences between benign and malignant Hurthle cell tumors of the thyroid. In this study, Ki67 was effective in distinguishing between some Hurthle cell carcinomas and adenomas, although there was overlap at the lower Ki67 LIs. As a group, the Ki67 LI was 3-fold higher in Hurthle cell carcinomas as compared with Hurthle cell adenomas. Our recent study found a 3 -fold increase in the LI of Ki67 in follicular carcinomas as compared with follicular adenomas, similar to the present study of Hurthle cell neoplasms (4). The
TABLE 5. Percentages of Cells Immunoreactive with Cyclin D1 Protein in Hurthle Cell Tumors

\begin{tabular}{lrrrrr}
\hline \multicolumn{1}{c}{ Diagnosis } & $N$ & \multicolumn{5}{c}{ Cyclin D1 } \\
\cline { 4 - 6 } & & $0 \%$ & $<5 \%$ & $5-25 \%$ & $>25 \%$ \\
\hline Hurthle cell adenoma & 59 & 42 & 14 & 2 & 1 \\
UMB & 14 & 8 & 4 & 2 & 0 \\
Hurthle cell carcinoma & 55 & 30 & 11 & 4 & $10^{a}$ \\
\hline UMB, uncertain malignant behavior. \\
a Although considerable variability was seen among the three groups, \\
diffuse ( $>25 \%$ nuclei positive) staining for cyclin D1 occurred more fre- \\
quently in Hurthle cell carcinomas compared with adenomas or UMB \\
tumors $(p=.006)$.
\end{tabular}

Ki67 LIs for Hurthle cell carcinomas $(10.0 \pm 1.2)$ and Hurthle cell adenomas $(3.2 \pm 0.3)$ are lower than the recently reported Ki67 LIs of follicular carcinomas (15.6 \pm 3.1$)$ and follicular adenomas (4.5 \pm 0.6$)$ (4). Although the number of cases of Hurthle cell tumors was greater than the follicular tumors in the previous study (4), these differences in Ki67 immunostaining suggest a higher proliferation rate in follicular tumors.

Hurthle cell carcinomas with vascular invasion showed a higher proliferative rate than tumors with only capsular invasion. Van Heerden et al. (31) reported that follicular carcinomas with vascular invasion had higher rates of distant metastases than follicular carcinomas with only capsular invasion, indicating that the type of invasive growth is important in predicting the behavior of follicular thyroid carcinomas. In our study, the nine cases of Hurthle cell carcinoma without vascular invasion 
neither had metastases at diagnosis nor subsequently developed metastases during the follow-up period. These findings suggest that vascular invasion may also be important in predicting the behavior of Hurthle cell thyroid carcinomas as it is in the closely related follicular carcinomas, which agrees with the previous report (31).

Several studies have suggested that tumor size is predictive of malignancy in Hurthle cell neoplasms (32-34). Recently, Chen et al. (32) reported that patients with Hurthle cell carcinomas had significantly larger tumors $(4.0 \mathrm{~cm})$ than those with Hurthle cell adenomas $(2.4 \mathrm{~cm})$ and concluded that size was predictive of malignancy in Hurthle cell neoplasms. Our observation that Hurthle cell carcinomas had a significantly larger mean tumor size than adenomas $(4.8 \mathrm{~cm}$ versus $3.1 \mathrm{~cm})$ agrees with previous studies, although considerable overlap was present. Carcangiu et al. (35) evaluated 153 Hurthle cell neoplasms and found that all tumors smaller than $1 \mathrm{~cm}$ were benign and all tumors larger than $10 \mathrm{~cm}$ were malignant. In the present series, we found that all tumors smaller than $1.1 \mathrm{~cm}$ were benign and all tumors larger than $8 \mathrm{~cm}$ were malignant. Perhaps even more important than the diagnosis of malignancy is the actual behavior of the neoplasm. Hurthle cell carcinomas with metastases had a significantly larger mean tumor size than Hurthle cell carcinomas without metastases. No patient in our study with a Hurthle cell neoplasm smaller than $3.5 \mathrm{~cm}$ in size had metastatic disease, even in the presence of vascular or capsular invasion. The larger mean tumor size of Hurthle cell carcinomas with metastases compared with those without metastases confirms the prognostic importance of tumor size in Hurthle cell neoplasms.

The Hurthle cell neoplasms of uncertain malignant behavior in our study behaved like Hurthle cell adenomas. No patient in the Hurthle cell adenoma group or UMB group developed metastatic disease. In their study of 153 Hurthle cell neoplasms Carcangiu et al. (35) included 35 cases classified as "indeterminate." They also found that the indeterminate lesions behaved in a clinically benign fashion. Tallini et al. (36) suggested that indeterminate categories not be used for Hurthle cell neoplasms "because in the absence of invasion, these neoplasms almost invariably behave in a benign fashion." We suggest that if extensive histologic evaluation reveals only equivocal capsular invasion and no vascular invasion, then the indeterminate lesions such as those in our UMB group should behave in a benign manner.

Recent studies have suggested that cyclin D1 may have a role in thyroid tumorigenesis $(5,6,37)$. In our study, diffuse staining for cyclin D1 was seen in a greater percentage of Hurthle cell carcinomas than adenomas or UMB tumors. These findings indicate that cyclin D1, which is a regulator of cell cycle progression, may be overexpressed in some Hurthle cell carcinomas. Zou et al. (5) found a 4- to 5 -fold increase in cyclin D1 expression in a subset of thyroid papillary carcinomas, compared with benign nodular goiters. Lazzereschi et al. (6) also found cyclin D1 overexpressed in a subset of papillary carcinomas without genetic alterations or amplification. In a recent study of 116 cases of thyroid tumors, Wang et al. (37) found cyclin D1 expression in $37(63 \%)$ cases of follicular variant of papillary carcinomas and in $34(60 \%)$ cases of follicular adenomas. There was no difference in cyclin D1 expression between these two groups. In the present study, we found that diffuse cyclin D1 protein expression was more common in Hurthle cell carcinomas compared with Hurthle cell adenomas. Because cyclin D1 staining was present in only a relatively small number of tumors, technical problems such as antigen preservation in formalin-fixed, paraffin embedded tissues probably contributed to suboptimal staining for cyclin D1 protein.

Historically, some authors had suggested that all Hurthle cell neoplasms should be regarded as malignant or potentially malignant (33). Our study indicates that Hurthle cell lesions without histologic evidence of vascular invasion after extensive sampling behave in a benign manner.

In summary, analyses of the cell cycle proteins Ki67 and cyclin D1 in Hurthle cell thyroid neoplasms indicate that these markers may assist in distinguishing between Hurthle cell carcinomas and adenomas in diagnostically difficult cases. Among the Hurthle cell carcinomas, large tumor size and vascular invasion are associated with clinically aggressive tumors. Our study also suggests that Hurthle cell neoplasms with only equivocal capsular invasion and no vascular invasion should behave in a benign manner.

\section{REFERENCES}

1. Watson RG, Brennan MD, Goellner JR, van Heerden JA, McConahey WM, Taylor WF. Invasive Hurthle cell carcinoma of the thyroid: natural history and management. Mayo Clin Proc 1984;59:851-5.

2. Carr K, Heffess C, Jin L, Lloyd RV. Immunohistochemical analysis of thyroid carcinomas utilizing antibodies to p53 and Ki67. Appl Immunohistochem 1993;1:201-7.

3. Pelosi G, Zamburi G. Proliferation markers and their uses in the study of endocrine tumors. Endocr Pathol 1996;7:103-19.

4. Erickson LA, Jin L, Wollan PC, Thompson GB, van Heerden J, Lloyd RV. Expression of p27kip1 and Ki67 in benign and malignant thyroid tumors. Mod Pathol 1998;11:169-74.

5. Zou M, Shi Y, Farid NR, Al-Sedairy ST. Inverse association between cyclin D1 overexpression and retinoblastoma gene mutation in thyroid carcinomas. Endocrine 1998;8:61-4.

6. Lazzereschi D, Sambuco L, Scalzo CC, Ranieri AR, Mincione G, Nardi F, et al. Cyclin D1 and cyclin E expression in 
malignant thyroid cells and in human thyroid carcinomas. Int J Cancer 1998;76:806-11.

7. Gerdes J, Lemke H, Baisch H, Wacker HH, Schwab U, Stein H. Cell cycle analysis of a cell proliferation-associated human nuclear antigen defined by the monoclonal antibody Ki67. J Immunol 1984;133:1710-5.

8. Matsushime H, Roussel MF, Ashmun RA, Sherr CJ. Colonystimulating factor 1 regulates novel cyclins during the G1 phase of the cell cycle. Cell 1991;65:701-13.

9. Won KA, Xiong Y, Beach D, Gilman MZ. Growth-regulated expression of D-type cyclin genes in human diploid fibroblasts. Proc Natl Acad Sci U S A 1992;89:9910-4.

10. Baldin V, Lukas J, Marcote MJ, Pagano M, Draetta G. Cyclin $\mathrm{D} 1$ is a nuclear protein required for cell cycle progression in G1. Genes Dev 1993;7:812-21.

11. Lukas J, Pagano M, Staskova Z, Draetta G, Bartek J. Cyclin D1 protein oscillates and is essential for cell cycle progression in human tumour cell lines. Oncogene 1994;9:707-18.

12. Motokura T, Bloom T, Kim HG, Juppner H, Ruderman JV, Kronenberg HM, et al. A novel cyclin encoded by a bcllinked candidate oncogene. Nature 1991;350:512-5.

13. Withers DA, Harvey RC, Faust JB, Melnyk O, Carey K, Meeker TC. Characterization of a candidate bcl-1 gene. Mol Cell Biol 1991;11:4846-53.

14. Buckley MF, Sweeney KJ, Hamilton JA, Sini RL, Manning DL, Nicholson RI, et al. Expression and amplification of cyclin genes in human breast cancer. Oncogene 1993;8:2127-33.

15. Fredersdorf S, Burns J, Milne AM, Packham G, Fallis L, Gillett $\mathrm{CE}$, et al. High level expression of p27kipl and cyclin D1 in some human breast cancer cells: inverse correlation between the expression of p27kipl and degree of malignancy in human breast and colorectal cancers. Proc Natl Acad Sci U S A 1997;94:6380-5.

16. Horenstein MG, Cesarman E, Wang X, Linkov I, Prieto VG, Louie CD. Cyclin D1 and retinoblastoma protein expression in Kaposi's sarcoma. J Cutan Pathol 1997;24:585-9.

17. Sutter T, Doi S, Carnevale KA, Arber N, Weinstein IB. Expression of cyclins D1 and $\mathrm{E}$ in human colon adenocarcinomas. J Med 1997;28:285-309.

18. Han EK, Lim JT, Arber N, Rubin MA, Xing WQ, Weinstein IB. Cyclin D1 expression in human prostate carcinoma cell lines and primary tumors. Prostate 1998;35:95-101.

19. Ishikawa T, Furihata M, Ohtsuki Y, Murakami H, Inoue A, Ogoshi S. Cyclin D1 overexpression related to retinoblastoma protein expression as a prognostic marker in human oesophageal squamous cell carcinoma. Br J Cancer 1998;77: 92-7.

20. Marchetti A, Doglioni C, Barbareschi M, Buttitta F, Pellegrini $\mathrm{S}$, Gaeta $\mathrm{P}$, et al. Cyclin D1 and retinoblastoma susceptibility gene alterations in non-small cell lung cancer. Int J Cancer 1998;75:187-92.

21. Jiang W, Kahn SM, Tomita N, Zhang YJ, Lu SH, Weinstein IB. Amplification and expression of the human cyclin $\mathrm{D}$ gene in esophageal cancer. Cancer Res 1992;52:2980-3.
22. Zukerberg LR, Yang W-I, Gadd M, Thor AD, Koerner FC, Schmidt EV, et al. Cyclin D1 (Prad1) protein expression in breast cancer: approximately one-third of infiltrating mammary carcinomas show overexpression of the cyclin D1 oncogene. Mod Pathol 1995;8:560-7.

23. Berenson JR, Koga H, Yang J, Pearl J, Holmes EC, Figlin R. The lung cancer study group: frequent amplification of the bcl-1 locus in poorly differentiated squamous cell carcinoma of the lung. Oncogene 1991;5:1343-8.

24. Proctor AJ, Coombs LM, Cairns JP, Knowles MA. Amplification at chromosome 11q13 in transitional cell tumors of the bladder. Oncogene 1991;6:789-95.

25. Nakagawa H, Zukerberg L, Togawa K, Meltzer SJ, Nishihara T, Rustoi A. Human cyclin D1 oncogene and esophageal squamous cell carcinoma. Cancer 1995;76:541-9.

26. Michalides R, van Veelen N, Hart A, Loftus B, Wientjens E, Balm A. Overexpression of cyclin D1 correlates with recurrence in a group of forty-seven operable squamous cell carcinomas of the head and neck. Cancer Res 1995;55:975-8.

27. Rosai J, Carcangui M, DeLellis R. Tumors of the thyroid gland. In: Rosai J, Sobin L, editors. Atlas of tumor pathology. 3rd series. Fasc. F. Washington, DC: Armed Forces Institute of Pathology; 1992.

28. Berho M, Suster S. The oncocytic variant of papillary carcinoma of the thyroid: a clinicopathologic study of 15 cases. Hum Pathol 1997;28:47-53.

29. Erickson LA, Jin L, Wollan P, Thompson GB, van Heerden JA, Lloyd RV. Parathyroid hyperplasia, adenomas, and carcinomas: differential expression of p27kip1 protein. Am J Surg Pathol 1999;23:288-95.

30. Weiss LM. Comparative histologic study of 43 metastasizing and non-metastasizing adrenocortical tumors. Am J Surg Pathol 1984;8:163-9.

31. van Heerden JA, Hay ID, Goellner JR, Salamao D, Ebersold JR, Bergstralh EJ, et al. Follicular thyroid carcinoma with capsular invasion alone: a non-threatening malignancy. Surgery 1992;112:1130-8.

32. Chen H, Nicol TL, Zeiger MA, Dooley WC, Landenson PW, Cooper DS, et al. Hurthle cell neoplasms of the thyroid: are there factors predictive of malignancy? Ann Surg 1998;227:542-6.

33. Thompson NW, Dunn EL, Batsakis JG, Nishiyama RH. Hurthle cell lesions of the thyroid gland. Surg Gynecol Obstet 1974;139:555-60.

34. Azadian A, Rosen IB, Walfish PG, Asa SL. Management considerations in Hurthle cell carcinoma. Surgery 1995;118:711-5.

35. Carcangiu ML, Bianchi S, Savino D, Voynick IM, Rosai J. Follicular Hurthle cell neoplasms of the thyroid gland: a study of 153 cases. Cancer 1991;68:1944-53.

36. Tallini G, Carcangiu ML, Rosai J. Oncocytic neoplasms of the thyroid gland. Acta Pathologica Japonica 1992;42:305-15.

37. Wang S, Wuu J, Savas J, Patwardhan N, Khan A. The role of cell cycle regulatory proteins, cyclin D1, cyclin E and p27 in thyroid carcinogenesis. Hum Pathol 1998;29:1304-9. 